Article

\title{
Financial Analysis of Potential Carbon Value over 14 Years of Forest Restoration by the Framework Species Method
}

\author{
Kanlayarat Jantawong ${ }^{1}\left(\mathbb{D}\right.$, Nuttira Kavinchan $^{2}$, Prasit Wangpakapattanawong ${ }^{3}$ and Stephen Elliott ${ }^{4, *(D)}$ \\ 1 Program in Environmental Sciences, Environmental Science Research Center, Faculty of Science, \\ Chiang Mai University, Chiang Mai 50200, Thailand; me_rat@yahoo.com \\ 2 Faculty of Sciences and Agricultural Technology, Rajamangala University of Technology Lanna Phitsanulok, \\ Phitsanulok 65000, Thailand; knuttira069@gmail.com \\ 3 Department of Biology and Environmental Science Research Center, Faculty of Science, \\ Chiang Mai University, Chiang Mai 50200, Thailand; prasitwang@yahoo.com \\ 4 Forest Restoration Research Unit, Environmental Science Research Center, Department of Biology, \\ Faculty of Science, Chiang Mai University, Chiang Mai 50200, Thailand \\ * Correspondence: stephen_elliott1@yahoo.com
}

check for updates

Citation: Jantawong, K.; Kavinchan, N.; Wangpakapattanawong, P.; Elliott, S. Financial Analysis of Potential Carbon Value over 14 Years of Forest Restoration by the Framework Species Method. Forests 2022, 13, 144. https://doi.org/10.3390/f13020144

Academic Editor: Mark E. Harmon

Received: 16 December 2021

Accepted: 9 January 2022

Published: 19 January 2022

Publisher's Note: MDPI stays neutral with regard to jurisdictional claims in published maps and institutional affiliations.

Copyright: (C) 2022 by the authors. Licensee MDPI, Basel, Switzerland. This article is an open access article distributed under the terms and conditions of the Creative Commons Attribution (CC BY) license (https:// creativecommons.org/licenses/by/ $4.0 /)$.

\begin{abstract}
The carbon storage value of forest restoration, by the framework species method (FSM) in northern Thailand, was assessed for trees (using a partial harvesting technique) and soil and compared with restoration costs. Forest carbon accumulation amounted to $143.08 \mathrm{tC} /$ ha in trees and $8.56 \mathrm{tC} / \mathrm{ha}$ in soil over 14 years, with a combined value of USD 27,173.63 (net present value (NPV), discounted at $2.85 \%$ /year)) (at the current European carbon credit (EUA) price of $55.98 \mathrm{EUR} / \mathrm{tCO}_{2}=242.21 \mathrm{USD} / \mathrm{tC}$ ). Restoration costs increased from 2190.27 to 5680.72 USD/ha with declining pre-existing natural regeneration or 3.99-10.34 USD per ton of sequestered $\mathrm{CO}_{2}$. Profits over 14 years ranged in NPV from 22,215.45 to 25,157.04 USD/ha, breaking even from just over 4 years to just under 7 , respectively. In contrast, profits from maize cultivation (a major regional deforestation driver) averaged 96.25 USD/ha/year, or just 1347.53 USD/ha over 14 years. Consequently, forest restoration could become a financially attractive alternative land use, provided an open, transparent, carbon market is created. Therefore, this study supports creation of a forest-carbon trading system in Thailand, to incentivize forest restoration and fire prevention, increase farmers' incomes, reduce smoke-related public health problems, protect watersheds, and conserve biodiversity.
\end{abstract}

Keywords: climate change; carbon credits; environment; forestry; forest restoration

\section{Introduction}

Interest in the major role that forest restoration could play in mitigating climate change, through carbon sequestration, has grown substantially in recent years [1]. From 1960 to 2015, total anthropogenic carbon emissions amounted to 408 PgC [2], with tropical forest destruction contributing about $8 \%$. Conservation, restoration, and improved management of tropical forests, mangroves, and peatlands could provide $23 \%$ of the mitigation action needed to limit global warming to $2{ }^{\circ} \mathrm{C}$ by 2030 [3].

Global recognition of the importance of forest restoration for climate change mitigation emerged in 2007, when "enhancement of carbon stocks" was included in the UN's REDD+ scheme (policies and incentives, developed under the UN Framework Convention on Climate Change, to finance forest conservation and restoration, by placing a value on the capacity of forests to absorb atmospheric carbon dioxide and thus mitigate global climate change) [4]. Four years later, the Bonn Challenge was launched, to restore forest to 350 million hectares of degraded land globally by 2030 [5], prompting a surge in large-scale tree-planting initiatives around the world. Lewis et al. [6] reported that natural forest restoration is the most effective land-use change technique for climate change mitigation, being 6 times more efficient at sequestering carbon than agroforestry and 40 times more 
efficient than conventional tree plantations. However, they also reported that only about one third of the area, pledged under the Bonn Challenge, and other national "restoration" efforts (for which planned methods are known), will be managed for natural forest regeneration; the rest will become plantations and agroforests. Clearly, greater financial incentives are needed, to support natural forest restoration.

REDD+ has encouraged the development of various funding mechanisms, to support large-scale forest restoration, e.g., the Green Climate Fund, carbon credit trading, etc. For example, in 2016, carbon trading, related to forestry and land use, accounted for $46 \%$ of total transactions on voluntary carbon markets (USD 67 million) [7].

Emission Trading Schemes (ETS) are the market mechanism used to reduce greenhouse gas emissions by the cap-and-trade system; "cap" being the upper limit of allowed greenhouse gas emissions. Under such schemes, one allowance unit, or carbon credit, grants the holder the right to emit 1 ton of $\mathrm{CO}_{2}$ (or its equivalent) [8]. Unused carbon credits can be traded. The European Union's Emissions Trading Scheme (EU ETS) is the world's largest, accounting for over three-quarters of international carbon trading [9]. Carbon credits under the system are termed EUAs.

Since causes of deforestation and forest degradation differ among countries, the success of REDD+ relies on cooperation among government agencies (at both national and local levels), forest communities and NGOs [10]. To qualify for REDD+, forest restoration must conform to UN safeguards, which include "full and effective engagement of indigenous peoples and local communities". This implies that restored forests should provide the full range of products and services, as the original forest once did. Secondly, actions must be "consistent with the conservation of natural forests and biological diversity and incentivize the protection and conservation of natural forests and their ecosystem services and enhance other social and environmental benefits" [11]. Consequently, tree planting for REDD+ initiatives must not displace existing forest nor infringe on the rights of local people. Neither of these conditions can be achieved by conventional, commercial plantations of fast-growing tree species [12,13]. Consequently, forest restoration must recreate the "look and feel" of old growth forest ecosystems, with the maximum biomass, structural complexity, biodiversity, and ecological functioning that are sustainable, within the limitations imposed by the prevailing climatic and edaphic conditions at any particular site [14]. However, evaluating carbon uptake of multi-species systems and analyzing the flows of costs and benefits are considerably more complex than they are for conventional tree plantations.

Our previous study [15] showed that average above-ground carbon (AGC), sequestered during restoration of tropical evergreen forest in northern Thailand by the framework species method (FSM), exceeded that of alternative land uses. A total of 5, 10 and 14 years after tree planting, AGC amounted to 13.2, 44.3, and 105.8 tC/ha, respectively. In contrast, Bridhikitti [16] reported much lower above-ground carbon stocks in sugarcane standing crops, degraded rain forest, mixed deciduous forest and mature rubber plantations of 11.1, $56.6,60.5$, and $91.5 \mathrm{tC} /$ ha, respectively.

The study, reported here, calculated the potential profits from carbon, accumulated during forest restoration by the FSM (Figure 1) in northern Thailand, by modeling the costs and the potential income that could be derived from such restoration, if the carbon sequestered could be monetized as carbon credits, paid for by carbon emitters. 


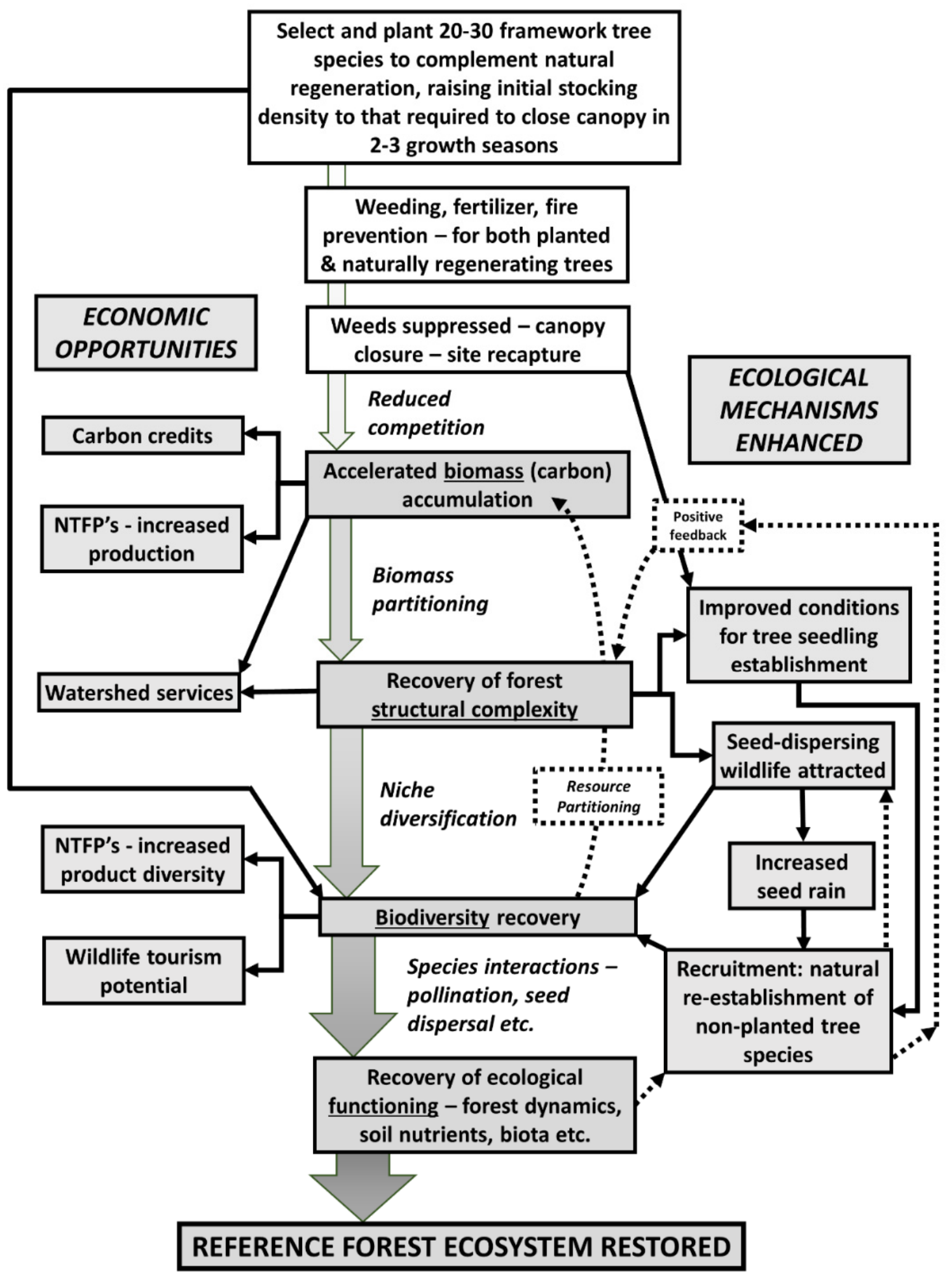

Figure 1. How the framework species method works. Wide grey arrows indicate progress of restoration; narrow black arrows indicate "origin affects destination", whilst dotted lines indicate positive feedback. 


\section{Materials and Methods}

\subsection{Study Site and Forest Restoration Method}

Quantities of carbon, sequestered in both above- and below-ground pools ( $\mathrm{tC} / \mathrm{ha})$ during forest restoration, were derived from two previously published studies by the current authors: Kavinchan [17,18] and Jantawong [15]. These studies were located in a chrono-sequence of experimental restoration plots, where the FSM had been tested, to restore seasonal upland evergreen forest in northern Thailand at elevations of 1200-1400 m above sea level. Plots had been established annually from 1997 to 2013 (spanning 16 years), by planting various combinations of 20-30 candidate framework tree species, mixing both pioneer and climax tree species [19] in the Upper Mae Sa Valley $\left(18^{\circ} 51^{\prime} 46.62^{\prime \prime} \mathrm{N}\right.$, $\left.98^{\circ} 50^{\prime} 58.81^{\prime \prime} \mathrm{E}\right)$. For full details of the study site and plot system, see Elliott et al. [20] and restor.eco (restor.eco/map/site/chiang-mai-vcnt3-4).

The FSM is used to restore forest ecosystem biomass, structure, biodiversity and ecological functioning, where management priorities include environmental protection, wildlife conservation and the provision of ecosystem services and a wide range of forest products (Figure 1). It involves planting mixtures of 20-30 indigenous tree species (both pioneer and climax species) that are characteristic of the target forest ecosystem, and are carefully selected for the following characteristics: (i) high survival and growth rates in exposed, deforested sites; (ii) broad, dense crowns that inhibit weeds and (iii) attractiveness to seed-dispersing animals (by producing fleshy fruits or other wildlife resources at a young age). The number of trees planted is that required to raise initial stocking density to 3100 trees / ha, considering the density of any natural regenerants (tree saplings $>50 \mathrm{~cm}$ tall, coppicing tree stumps and remnant mature trees) already present on the restoration site. This density ensures that canopy closure starts to occur at the end of the second rainy season after planting and is more or less complete by the end of the third rainy season. The FSM therefore complements "assisted natural regeneration" (ANR) with tree planting. Maintenance, of both the planted trees and natural regenerants, includes weeding and fertilizer application, 3 times per year for the first 2 years. Therefore, costs of implementing the FSM vary, depending on the initial density of natural regenerants (Figure 2). See Goosem and Tucker [21] for the origins of the technique in Australia and Elliott et al. [19] for its development in Thailand.

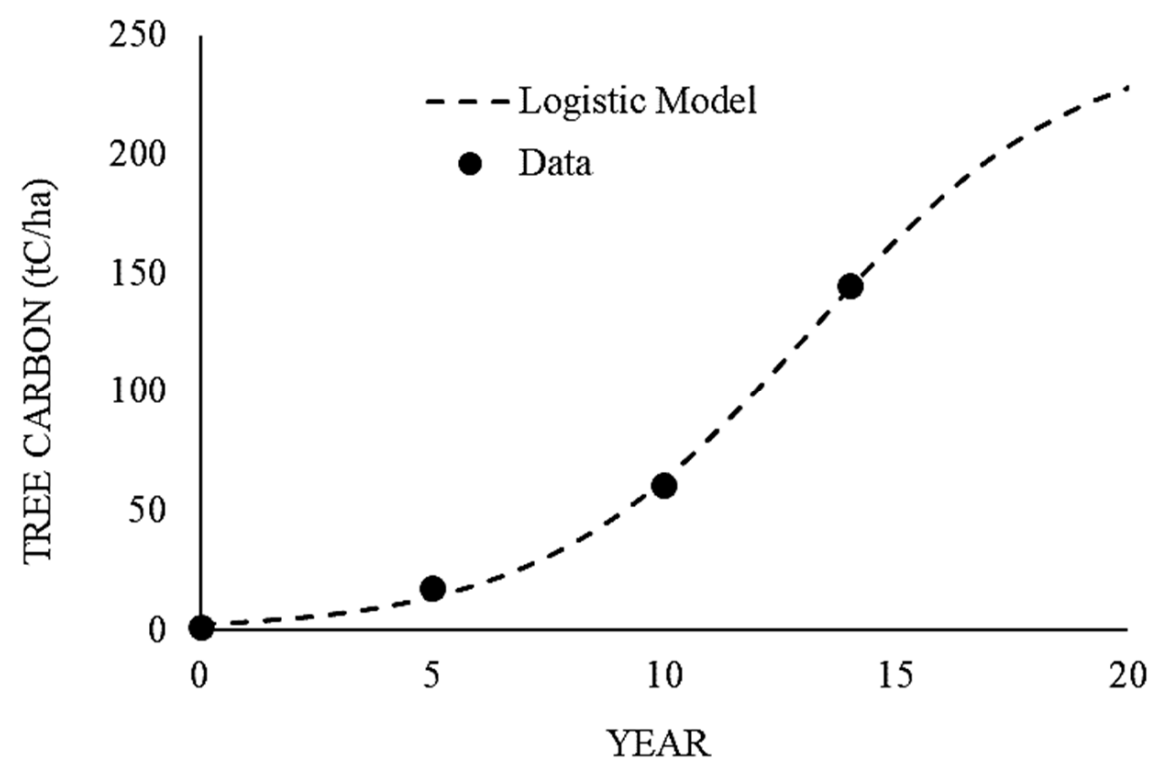

Figure 2. Modeled tree-carbon accumulation during forest restoration by the framework species method, including above- and below-ground parts. 


\subsection{Carbon Accumulation in Trees and Soil}

Derivation of above-ground tree biomass (AGTB) was described in Jantawong [15], using a partial harvesting method [22] applied to 11 framework tree species (Table 1). Detailed measurements of tree parts, including sample branches cut from each tree, was used to calculate tree volume and wood density. Total carbon stored in each tree was derived by multiplying tree volume by wood density and percent carbon content. Branches were categorized as primary, secondary, tertiary and so on. Primary branches were those growing out from the main trunk; secondary branches were those that grew out from primary branches, whilst tertiary branches grew out from the secondary branches. Primary branches were counted, and one was cut from each sample tree to measure length and circumference. Trunk diameter was measured at the base and top and the trunk volume was calculated, using the formula for a frustum cone (Equation (1)).

$$
\text { trunk volume }=\frac{\pi h}{3} \times\left(\mathrm{R}^{2}+\mathrm{Rr}+\mathrm{r}^{2}\right)
$$

where $\mathrm{h}=$ height, $\mathrm{R}=$ lower girth and $\mathrm{r}=$ upper girth

Table 1. Tree species included in this study.

\begin{tabular}{cccc}
\hline No. & Species & Successional Status & Leafing \\
\hline 1 & Bischofia javanica & Pioneer & Deciduous \\
2 & Erythrina subumbrans & Pioneer & Deciduous \\
3 & Gmelina arborea & Pioneer & Deciduous \\
4 & Heynea trijuga & Climax & Semi-deciduous \\
5 & Hovenia dulcis & Climax & Deciduous \\
6 & Melia toosendan & Pioneer & Deciduous \\
7 & Nyssa javanica & Pioneer & Evergreen/semi-deciduous \\
8 & Prunus cerasoides & Pioneer & Deciduous \\
9 & Sapindus rarak & Climax & Deciduous \\
10 & Sarcosperma arboreum & Climax & Evergreen \\
11 & Spondias axillaris & Pioneer & Deciduous \\
\hline
\end{tabular}

The density of wood samples was determined and their percent carbon content was measured with a carbon $(\mathrm{C})$, hydrogen $(\mathrm{H})$, nitrogen $(\mathrm{N})$ elemental analyzer. Samples were processed through flash combustion, separated by a chromatographic column and components detected by a Thermal Conductivity Detector [23].

AGTB data were collected for 11 tree species ( 3 replicates each) in plots aged 5, 10, and 14 years old, since tree planting (the R5, R10, and R14 plots, planted in 2007, 2002, and 1998; each plot had 3 replicated subplots measuring $40 \times 40 \mathrm{~m}^{2}$ ) and adjacent control plots, left to regenerate naturally. Carbon in tree roots was estimated by multiplying above-ground tree carbon by 0.37 , as recommended by the IPCC [24] for tropical evergreen forests. Field data from restoration and control plots were fitted to a logistic model (with CurveExpert Basic).

$$
\text { Tree carbon }(\mathrm{tC} / \mathrm{ha})=\mathrm{a} /\left(1+\mathrm{be}^{(-\mathrm{cY})}\right)
$$

where $\mathrm{a}=$ the upper asymptote (measured carbon in nearby mature forest at 60 years), $\mathrm{e}=$ Euler's number, $\mathrm{b}$ and $\mathrm{c}$ are empirically derived parameters and $\mathrm{Y}=$ the number of years since start of restoration interventions. The equation was used to generate the annual carbon revenue figures for calculation of NPV within the 14-year time span of the field data.

Although Kavinchan et al. [17] measured soil carbon (SC) in the same plots in 2009, she did so at different ages $(2,7$, and 11 years old) to those sampled for AGTB. Therefore, the R5, R10, and R14 plots were re-sampled in 2017. Soil samples were taken at depths of $10,20,30,40$, and $50 \mathrm{~cm}$, using a soil auger in $50 \mathrm{~cm}$ deep pits $(n=3)$. Soil samples were oven-dried and sieved to exclude roots. Organic matter was determined, using the method of Walkley and Black [25], and a Van Bemmelen value of 0.58 was used to convert 
soil organic matter into soil organic carbon [26]. Kavinchan et al.'s original published equations [17] were then used to extrapolate soil carbon down to a depth of $2 \mathrm{~m}$ from the measurements made in the upper $50 \mathrm{~cm}$. The increase in soil carbon between 2009 and 2017 in plots of three different ages was then calculated.

In addition, soil-carbon accumulation was modeled from net inputs of carbon into the soil via litterfall, measured with litterfall traps, minus the decomposition rates for plots of 3 different ages, measured using litter bags, as published by Kavinchan et al. [18] for the same plots. For that study, plastic litter traps, $1 \times 1 \mathrm{~m}^{2}$, were suspended $15 \mathrm{~cm}$ above the ground in each study plot. Subsamples of about $10 \%$ of the litter from the traps were collected at the start of the experiment (April) and subsequently in the mid-rainy season (August), cool season (November) and cool-dry season (February) for moisture content determination. Each time, the litter bags were weighed, and the remaining dry mass of litter was used, to derive decomposition rates (Equation (3)).

$$
\% \text { mass loss }=(\mathrm{W} 1-\mathrm{W} 2) / \mathrm{W} 1 \times 100
$$

where $\mathrm{W} 1$ = the original dry mass of litter, $\mathrm{W} 2$ = the dry mass of litter after time $\mathrm{t}$, and \% mass remaining $=100-\%$ mass loss. Collected litter was oven-dried at $80{ }^{\circ} \mathrm{C}$ [27], and then analyzed for organic carbon, using the standard technique of Walkley and Black [25].

\subsection{Financial Modeling}

Restoration costs were those calculated by FORRU-CMU (unpublished), for the year 2021. They included the total local field costs of all tasks and materials, required to restore forest to a closed-canopy condition over 2 years, including: site preparation, planting stock production (from local seed collection and germination, to delivery of containerized saplings, 30-50 cm tall, of required species), planting, maintenance (weeding and fertilizer application) and monitoring for 2 rainy seasons after planting (by which time canopy closure usually negates the need for further weeding). Field labor costs were local costs for Chiang Mai Province (9.65 USD/day), assuming no voluntary labor.

The costs also included management inputs, including a baseline site survey for project planning, training, overseeing maintenance and monitoring, as well as reporting and accounting. Since some management costs were independent of area restored (e.g., reporting, accounting, etc.), costs per hectare decline slightly as the area restored increases. Therefore, all costs were standardized, assuming an area of 10 ha was restored. Management inputs were costed at $28.79 \mathrm{USD} /$ person/day; standard local rate for a Bachelor's-level graduate.

The financial model assumes that farmers borrow the full amount, needed to cover the establishment costs of forest restoration, from the Bank for Agriculture and Agricultural Cooperatives (BAAC), paying back the interest and principal from carbon income, until break-even. The bank has a long history of investing in agriculture and forestry projects, providing loans specifically for "forest planting, including land preparation, planting seedling and supplies for forest planting" [28] at a rate of $4.875 \%$ (effective since 1 June 2020) [29].

Since Thailand has yet to establish a central carbon market, carbon value was calculated as the combined tree- and soil-carbon increment (above initial control) multiplied by EUA price - the carbon price on the EU Emissions Trading System (EU-ETS) - 55.98 $\mathrm{EUR} / \mathrm{tCO}_{2}=\mathrm{USD} 66.06$ [30], at 1.18 USD/EUR (as of August 2021) [31]. Readers may update the carbon value and adjust the calculations accordingly, at the time of reading, by referring to https://ember-climate.org/data/carbon-price-viewer/ (accessed on 14 September 2021).

Since income from carbon accumulation is initially low, rising rapidly in later years, a discount rate was applied, to arrive at a net present value (NPV) of future carbon income. The discount rate combined the interest rate that money would earn if left in a bank with depreciation due to inflation (Equation (4)).

$$
\text { Discount rate }=(1+\text { real interest rate }) \times(1+\text { inflation rate })-1
$$


Total NPV of the carbon value of restoration was calculated as the sum the NPVs of profits for each year, over the 14 years after initiation of restoration (Equation (5)).

$$
\mathrm{NPV}=\sum_{\mathrm{t}=0}^{\mathrm{n}} \frac{\mathrm{FV}}{(1+\mathrm{r})^{\mathrm{t}}}
$$

where NPV = net present value (USD), FV = future value (USD), $r=$ discount rate, $t=$ year (value of 0 to " $n$ ") and $n=$ project period.

\section{Results}

\subsection{Tree- and Soil-Carbon Value}

Over the first 14 years, following initiation of restoration interventions (tree planting, maintenance, and assisted natural regeneration (ANR)), tree carbon increased by $143.08 \mathrm{tC} /$ ha (Table 2) above control level.

Table 2. Potential value of incremental tree carbon, during restoration of upland evergreen forest in northern Thailand by the framework species method.

\begin{tabular}{cccc}
\hline $\begin{array}{c}\text { Forest Age (Since Start } \\
\text { of Restoration) }\end{array}$ & Tree Carbon Stock ${ }^{\mathbf{1}}$ & Increment & $\begin{array}{c}\text { Increment Potential } \\
\text { Cash Value }\end{array}$ \\
\hline (Year) & (tC/ha) & $\mathbf{( t C / h a )}$ & (USD) \\
\hline 0 & 1.73 & - & - \\
\hline 5 & 18.04 & 16.31 & 3950.39 \\
\hline 10 & 60.75 & 42.71 & $10,344.65$ \\
\hline 14 & 144.81 & 84.06 & $20,359.90$ \\
\hline Total (0-14 Y) & & 143.08 & $34,654.95$ \\
\hline
\end{tabular}

${ }^{1}$ Mean above-ground tree carbon (across species) $\times 1.37$ (to add roots [24]) $\times$ measured numbers of surviving trees per hectare [15]. ${ }^{2}$ Assuming EUA price of EUR 55.98 per ton $\mathrm{CO}_{2}$, converted to USD/tC: multiplied with the proportion of molecular weight of $\mathrm{CO}_{2}$ to $\mathrm{C}(44 / 12)$ at $1.18 \mathrm{USD} / \mathrm{EUR}=242.21 \mathrm{USD} / \mathrm{tC}$ (as of August 2021).

The tree-carbon field data in Table 2 were combined with measured tree carbon in nearby disturbed primary forest $(248.60 \mathrm{tC} / \mathrm{ha}$, at 60 years $)$ to determine the parameters in the logistic forest-growth model (Equation (2)), resulting in the following equation (Equation (6)).

$$
\text { Tree carbon }(\mathrm{tC} / \mathrm{ha})=248.6712 \div\left(1+95.7167 \times 2.7183^{(-0.3483 \mathrm{Y})}\right)
$$

where $\mathrm{Y}=$ years since tree planting.

The logistic model (Figure 2) had a very high co-efficient of determination $\left(R^{2}=0.99\right)$ and was therefore used to calculate annual cash flows and derive NPVs of potential carbon profits in the cash flow model below. At the time of writing (September 2021), the trading price of 1 ton of $\mathrm{CO}_{2}$ on the European Emission Allowance (EUA) market was $55.98 \mathrm{EUR} / \mathrm{tCO}_{2}$, which converted to $242.21 \mathrm{USD} / \mathrm{tC}\left(\mathrm{CO}_{2} \times 44 / 12\right.$ (ratio molecular weight $\mathrm{CO}_{2}$ to $\mathrm{C}$ ), at $1.18 \mathrm{USD} / \mathrm{EUR}$, as of August 2021). Therefore, $143.08 \mathrm{tC} /$ ha at 14 years had a calculated (non-discounted) cash value of 34,654.95 USD/ha.

Comparison of soil-carbon stock among plots of different ages in different places could not be used to calculate carbon accumulation, since land use history (rather than time since initiation of restoration) had a legacy effect that overwhelmed changes expected from forest restoration. For example, soil-carbon measurements, reported by Kavinchan et al. [17] and repeated during the present study, confirmed much lower soil carbon in the oldest plots, compared with the youngest plots (Table 3). This was probably due to intensive cultivation for cabbages in the older plots, resulting in soil erosion, over many years prior to restoration (interview with Mr. Kasem, former farmer of the site). 
Table 3. Changes in measured soil carbon between two surveys 8 years apart.

\begin{tabular}{|c|c|c|c|c|c|c|}
\hline \multirow{2}{*}{$\begin{array}{l}\text { Year Plots Planted> } \\
\text { Plot age (years since } \\
\text { restoration initiated) }\end{array}$} & \multicolumn{2}{|c|}{2007} & \multicolumn{2}{|c|}{2002} & \multicolumn{2}{|c|}{1998} \\
\hline & 2 & 10 & 7 & 15 & 11 & 19 \\
\hline $\begin{array}{l}\text { Kavinchan et al. (2015a) } \\
\text { (tC/ha)-down to } 2 \mathrm{~m} \text { depth } \\
\text { (in 2009) }\end{array}$ & 254.40 & & 251.14 & & 161.82 & \\
\hline $\begin{array}{c}\text { This study (tC/ha) }-0-50 \mathrm{~cm} \text { depth } \\
\text { extrapolated down to } 2 \mathrm{~m} \text { using } \\
\text { Kavinchan et al. [17] equations } \\
\text { (in 2017) }\end{array}$ & & 261.77 & & 255.75 & & 170.39 \\
\hline $\begin{array}{l}\text { Soil-carbon accumulation over } \\
8 \text { years (tC/ha) (measured) }\end{array}$ & & 7.37 & & 4.61 & & 8.57 \\
\hline $\begin{array}{c}\text { Average annual soil-carbon } \\
\text { increase (measured) (tC/ha/year) }\end{array}$ & & 0.92 & & 0.58 & & 1.07 \\
\hline $\begin{array}{l}\text { Litter-carbon accumulation over } \\
8 \text { years (modeled) }\end{array}$ & & 1.11 & & 3.84 & & 10.73 \\
\hline $\begin{array}{c}\text { Average annual litter-carbon } \\
\text { increase (measured) (tC/ha/year) }\end{array}$ & & 0.14 & & 0.48 & & 1.34 \\
\hline Ratio soil-carbon:litter-carbon & & 6.65 & & 1.20 & & 0.80 \\
\hline
\end{tabular}

Annual soil-carbon accumulation rates were estimated from increases in measured soil carbon over the 8 years, from Kavinchan's original measurements in 2009 [17] to the re-survey performed in 2017 in plots of three ages. Measured soil-carbon increased in all plots surveyed, but the sizes of the increases were not related consistently with plot age. Increases over 8 years were $7.37 \mathrm{tC} /$ ha (plot 2007), 4.61 (plot 2002), and 8.57 (plot 1998), averaging $0.92,0.58$, and $1.07 \mathrm{tC} / \mathrm{ha} /$ year, respectively (Table 3 ).

Using plot-age-specific measurements of litter fall and decomposition rates, published by Kavinchan [18], a model was constructed to estimate the accumulation of litterfall carbon in the soil over time. The model underestimated soil-carbon accumulation for young plots and overestimated it for older plots (Table 3). Annual net litter carbon accumulation in the soil (taking into account decomposition) amounted to $1.5-2.5 \%$ of tree- carbon stock (including roots). The mean ratio of measured soil-carbon accumulation to modeled leaflitter-carbon accumulation was 2.88. Therefore, a multiplication factor of 2.88 was applied to the leaf litter model, to arrive at a rough estimate of soil-carbon accumulation, related to forest age and independent of site history. Thus, estimated soil carbon accumulated at 14 years was $8.56 \mathrm{tC} / \mathrm{ha}$, with a (non-discounted) cash value of 2073.10 USD/ha.

Therefore, the combined increase in tree and soil carbon, resulting from forest restoration by the FSM over the first 14 years, amounted to $151.64 \mathrm{tC} / \mathrm{ha}$, with a (non-discounted) value of USD 36,728.05 (94.36\% from trees and 5.64\% from soil). Applying a discount rate of $2.85 \%$ to carbon revenue each year, over 14 years, (Equation (4)), which combined the Thai bank annual deposit rate of 1.66\% (averaged from 2011 to 2020 [32]) with the Thailand annual inflation rate of $1.18 \%$ (averaged from 2011 to 2020), resulted in an NPV of 27,173.63 USD/ha for potential carbon revenue. The next step was to subtract restoration costs to arrive at overall potential profit.

\subsection{Restoration Costs}

Since caring for pre-existing natural regenerants entails neither nursery production costs nor planting costs, overall restoration costs decline with their increasing initial density (Figure 3). 


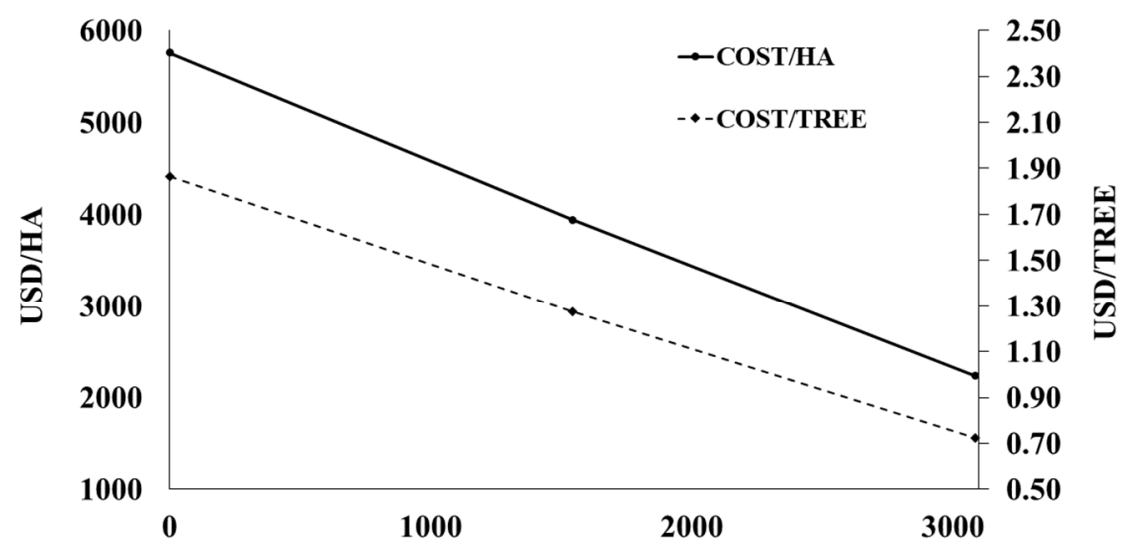

INITIAL STOCKING DENSITY NATURAL REGENERANTS/HA

Figure 3. Forest restoration costs decline with increasing density of pre-existing natural regenerants (assuming 10 ha restored) (includes field costs, interest on loans, and $10 \%$ contingency for unanticipated transaction costs) (data from FORRU-CMU, August 2021).

Table 4 presents a detailed breakdown of the costs of implementing the FSM in northern Thailand, following well-tested standard procedures [14], where the density of pre-existing natural regenerants is minimal, or high enough to close canopy within two rainy seasons (>3100/ha) or mid-way in between (1550/ha). The figures assume an area of 10 ha is restored and that all labor is paid for (i.e., no voluntary labor).

Table 4. Costs of the framework species method (USD/ha) by standard procedures [14] (Elliott et al., 2013), with initial stocking densities of 0,1543 , and 3100 regenerants/ha $(0,50 \%$ and $100 \%$ of that required to initiate canopy closure within two rainy seasons), for a 10-ha site (data from Chiang Mai University's Forest Restoration Research (FORRU-CMU), August 2021). ANR = assisted natural regeneration.

\begin{tabular}{|c|c|c|c|c|c|c|c|c|c|}
\hline \multirow{2}{*}{$\begin{array}{c}\text { Field Establishment Costs } \\
\text { By budget items }\end{array}$} & \multicolumn{3}{|c|}{$100 \%$ Tree Planting } & \multicolumn{3}{|c|}{ Tree Planting: ANR 50:50 } & \multicolumn{3}{|c|}{$100 \%$ ANR } \\
\hline & Y1 & Y2 & TOTAL & Y1 & $\mathrm{Y} 2$ & TOTAL & Y1 & Y2 & TOTAL \\
\hline Planting stock & 1838.00 & 0.00 & 1838.00 & 919.00 & 0.00 & 919.00 & 0.00 & 0.00 & 0.00 \\
\hline Materials and equipment & 315.37 & 129.03 & 444.40 & 253.80 & 129.03 & 382.83 & 192.23 & 129.03 & 321.26 \\
\hline Transportation & 145.50 & 23.94 & 169.44 & 99.55 & 23.94 & 123.49 & 53.60 & 23.94 & 77.54 \\
\hline Labor & 1033.30 & 549.05 & 1582.35 & 874.00 & 546.56 & 1420.56 & 714.71 & 544.07 & 1258.78 \\
\hline Quantifiable transaction costs & 54.42 & 20.61 & 75.03 & 54.42 & 20.61 & 75.03 & 54.42 & 20.61 & 75.03 \\
\hline Total field costs by budget item & 3386.59 & 722.63 & 4109.22 & 2200.77 & 720.14 & 2920.91 & 1014.96 & 717.65 & 1732.61 \\
\hline \multicolumn{10}{|l|}{ By task } \\
\hline Pre-planting site survey & 13.07 & 0.00 & 13.07 & 13.07 & 0.00 & 13.07 & 13.07 & 0.00 & 13.07 \\
\hline Site preparation & 297.40 & 0.00 & 297.40 & 244.10 & 0.00 & 244.10 & 190.80 & 0.00 & 190.80 \\
\hline Tree planting (+initial ANR tasks) & 2346.20 & 0.00 & 2346.20 & 1218.59 & 0.00 & 1218.59 & 90.98 & 0.00 & 90.98 \\
\hline Maintenance (weeding, fertilizer) 2 years & 693.97 & 704.38 & 1398.36 & 693.97 & 704.38 & 1398.36 & 693.97 & 704.38 & 1398.36 \\
\hline Monitoring -2 years & 35.94 & 18.24 & 54.19 & 31.04 & 15.75 & 46.80 & 26.14 & 13.27 & 39.41 \\
\hline Total field costs by task & 3386.59 & 722.63 & 4109.21 & 2200.77 & 720.14 & 2920.91 & 1014.96 & 717.65 & 1732.61 \\
\hline $\begin{array}{l}10 \% \text { contingency for unanticipated } \\
\text { transaction costs }\end{array}$ & 338.66 & 72.26 & 410.92 & 220.08 & 72.01 & 292.09 & 101.50 & 71.77 & 173.26 \\
\hline SUBTOTAL & 3725.25 & 794.89 & 4520.14 & 2420.85 & 792.15 & 3213.00 & 1116.45 & 789.42 & 1905.87 \\
\hline INTEREST & & & 1160.59 & & & 672.39 & & & 284.40 \\
\hline GRAND TOTAL (USD) & & & 5680.72 & & & 3885.39 & & & 2190.27 \\
\hline Costs per tC sequestered (USD/tC) & & & 10.34 & & & 7.07 & & & 3.99 \\
\hline Costs per tree established (USD/tree) & & & 1.83 & & & 1.25 & & & 0.71 \\
\hline
\end{tabular}


Basic field costs (materials, labor, and known transaction costs), spread over the first 2 years, ranged from $1732.61 \mathrm{USD} / \mathrm{ha}$, for 100\% ANR (no trees planted) to $4109.21 \mathrm{USD} / \mathrm{ha}$, where maximum tree planting $(3100 / \mathrm{ha})$ is required. To basic field costs a $10 \%$ contingency was added, to cover unanticipated transaction costs. Known transaction costs (planning, training, monitoring, reporting and accounting) were already included in basic field costs. Interest payments were also added, assuming that farmers would borrow the full amount required to implement restoration (including a 10\% contingency), at interest rates that are currently offered by the Bank for Agriculture and Agricultural Cooperatives (BAAC) for forestry purposes (4.875\% per year). We further assumed that income from carbon sequestration would first be used to pay back both the interest and principal. Therefore, total costs ranged from 2190.27 to $5680.72 \mathrm{USD} / \mathrm{ha}$, depending on the initial state of forest regeneration (Table 4 ) or 3.99 to $10.34 \mathrm{USD} / \mathrm{tCO}_{2}$ sequestered.

\subsection{Financial Modeling}

Figure 4 shows potential cash balance over 14 years, starting at three different levels of natural forest regeneration (using Equation (6) for tree carbon). The model includes restoration costs (including 10\% contingency), interest payments on the remaining principle each year, and the potential carbon credit value, if carbon were traded at the EUA market price. Predicted undiscounted net profits at year-14 ranged from 30,598.20 to $34,088.65$ USD/ha (from most to least degraded initial conditions), resulting in NPVs of $22,215.45$ to 25,157.04 USD/ha, respectively. Establishment costs are high and are incurred in the first 2 years, whilst carbon accumulation (and the potential income derivable therefrom) is initially slow. Consequently, loan repayments are low over the first few years resulting in debt. The model predicts that it would take about 4 years to break-even on the least degraded sites, increasing to just under 7 years on the most degraded sites. After that, profits would accrue rapidly.

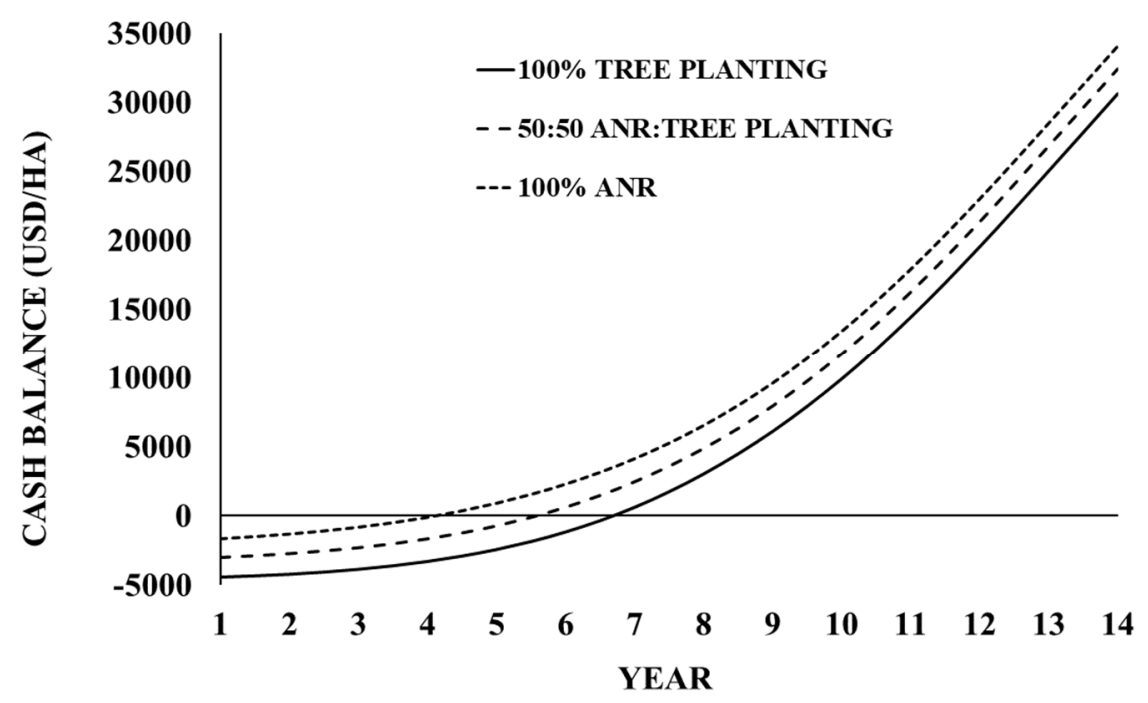

Figure 4. Modeled cash flows during forest restoration by the framework species method for carbon sequestration-assuming full establishment costs are borrowed and carbon could be marketed at the EUA price.

\subsection{Comparison with Maize Farming}

According to the Office of Agricultural Economics, Ministry of Agriculture and Cooperatives [33], the average maize yield in northern Thailand (2019) was $4.4 \mathrm{t} / \mathrm{ha}$, with a national, average, farm-gate, price of $232.58 \mathrm{USD} / \mathrm{t}$, (January-August 2020; $7.81 \mathrm{THB} / \mathrm{kg}$ at $33.58 \mathrm{THB} / \mathrm{USD}$, exchange rate as of 01/09/21 [34]). Therefore, average revenue was about 1023.35 USD/ha/year. Average production costs in 2019 were 884.00 USD/ha [33]. Adding the costs of borrowing to fund inputs, using the same BAAC interest rate of $4.875 \%$ as for forest restoration costs, brings total maize farming costs to $927.10 \mathrm{USD} / \mathrm{ha}$, leaving a net 
profit of just 96.25 USD/ha/year, which amounts to 1347.53 USD/ha over the same 14-year cycle period, as used for the forest carbon model.

Abandoned maize fields support little, if any, natural forest regeneration. Therefore, conversion back to forest, using the FSM, would require planting the full complement of 3100 trees per hectare and incur the highest costs (5680.72 USD/ha (Table 4)) but would yield a profit over 14 years with an NPV of USD 22,215.45-that is more than 16 times higher than the profit from maize cultivation. Such a large difference in potential profits would constitute a powerful financial incentive for farmers to switch from maize cultivation to forest restoration for carbon.

The carbon price would have to drop to below $60.14 \mathrm{USD} / \mathrm{tC}$ (i.e., an EUA of $<13.9 \mathrm{EUR}$ per ton $\mathrm{CO}_{2}$ ) before maize cultivation would become more profitable than forest carbon, at current maize prices and yields. Conversely, at the current carbon price, the maize price would have to increase to $571 \mathrm{USD} / \mathrm{t}$ before maize became more profitable than carbon. In general, carbon would be more profitable than maize production, when the carbon price $(\mathrm{USD} / \mathrm{tC})$ is higher than $(0.5412 \times$ maize price $(\mathrm{USD} / \mathrm{t})-67.14)$ (the equation for the solid black line in Figure 5).

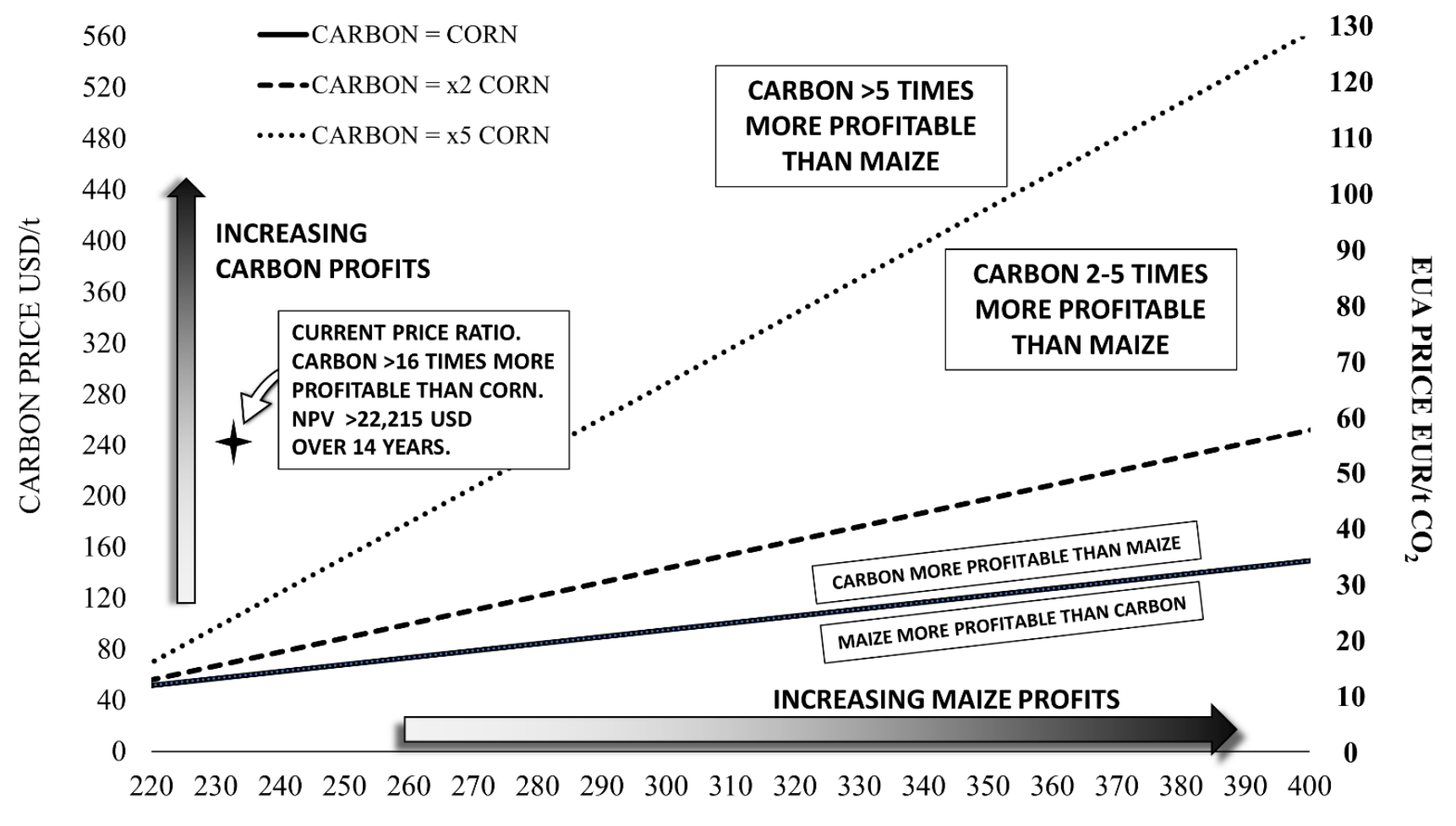

MAIZE FARM GATE PRICE USD/t

Figure 5. Relative profitability of maize or carbon with various price ratios. (The star indicates the current price ratio).

\section{Discussion}

\subsection{Carbon}

The financial model is based on original carbon data, collected by the authors $[15,17,18]$, from a long-term, replicated, controlled, restoration, field-plot system, also designed and established by the authors and published in peer-reviewed journals [20]. Results were specific for upland, seasonally dry, tropical evergreen forest, undergoing restoration by the FSM in northern Thailand. Fundamental to the FSM is the selection of tree species, with high rates of survival and growth, when out-planted on exposed deforested sites and are typical of the target forest ecosystem. Furthermore, the method raises the initial 
stocking density to a high level (3100/ha) by complementing natural regenerants with planted trees [14]. Thus, rapid carbon accumulation is achieved by design.

Not surprisingly, therefore, rates of carbon accumulation, using the FSM, were higher than those reported for natural regeneration of similar forest systems. In terms of aboveground tree biomass (AGTB), we estimated an average gain of $237 \mathrm{t} / \mathrm{ha}(106 \mathrm{tC} / \mathrm{ha})$ in framework species trial plots, over 14 years [15], almost double the pan-tropical average, estimated by Silver et al. [35] $124 \mathrm{t} / \mathrm{ha}$ ( $58 \mathrm{tC} / \mathrm{ha}$ ), over the first 20 years of natural forest succession. It is also much higher than Jha et al.'s [36] report of a mean gain in aboveground biomass of $143 \mathrm{t} / \mathrm{ha}(67 \mathrm{tC} / \mathrm{ha})$ over the first 20 years of natural regeneration in Khao Yai National Park, Central Thailand (with similar climatic conditions as the present study), derived from remote-sensing data. In addition, it contrasts starkly with the AGTB of 17-year-old teak plantations in western Thailand-just $34 \mathrm{t} / \mathrm{ha}(16 \mathrm{tC} / \mathrm{ha})$ [37]. Furthermore, tree-carbon stocks in the restoration plots in the present study, exceeded those in nearby old growth forest remnants 16-17 years after initiating restoration interventions [15]. Therefore, our findings indicate that deliberate selection of indigenous forest tree species for high rates of survival and growth, as framework tree species, could substantially increase the carbon storage potential of forest restoration projects and maximize potential carbon income, during at least the first two decades after initiating restoration interventions.

The model is specific for the early establishment phase of forest restoration (first 14 years), during which annual carbon increment increases almost exponentially-a pattern also reported by Jha et al. [36] for young forest. Obviously, this will not continue indefinitely. The data already show signs of decelerating growth; the ratio of increment to standing crop data in Table 2 declined with increasing plot age from 0.90 ( $1-5$ years) to 0.70 (5-10 years) and 0.58 (10-14 years), hence our use of a logistic model to generate annual estimates of carbon accumulation (Equation (6), Figure 2).

This is expected since, as trees age, carbon respired by non-photosynthetic, structural, tree organs increases disproportionately more than that fixed by photosynthesis [38]. Brown and Lugo [39] and Silver et al. [35] reported that carbon accumulation rates, in recovering tropical secondary forests, decrease after 50-60 years and Chayaporn et al. [37] also presented a logistic growth model for teak trees in Thailand, which trends towards an asymptote at 80-90 years. Clearly, additional data on the carbon balance in the later stages of logistic growth are needed, to compare carbon revenue, with other land uses over a longer time span. In the present study, we do not speculate beyond the age range of our field data (14 years).

Soil-carbon stocks ranged from 162 to $262 \mathrm{tC} /$ ha across the plot system (Table 3). Therefore, the percent of total ecosystem carbon in the soil ranged from $94 \%$, when the trees were very young, to $54 \%$ at 14 years. The latter is very close to the 50:50 division of carbon stocks between vegetation and soils, typical of tropical moist forests $(1000-2500 \mathrm{~mm}$ annual rainfall) [40]. In contrast, our modeled rates of soil-carbon accumulation, which averaged $0.61 \mathrm{tC} / \mathrm{ha} /$ year over the first 14 years, were below typical values (e.g., pan tropical average of $1.30 \mathrm{tC} / \mathrm{ha}$ /year over the first 20 years of forest regeneration on abandoned agricultural land [35]). This may have been due to underestimation of litter production or overestimation of decomposition rates (from the litter bag experiments [18]) and requires further investigation. However, it does mean that estimates of revenue from soil carbon, in the financial model, were most likely conservative.

\subsection{Costs and Revenue}

Restoration costs (Table 4) depended on the original extent of natural regeneration (Figure 3), since the FSM complements ANR with tree planting [14]. Stocking density of natural regenerants per hectare is first surveyed, using circular sample plots [14]. If their estimated density is higher than $3100 /$ ha, no trees need be planted, since restoration can be achieved by ANR alone. However, if the density is below $3100 /$ ha, then framework trees are planted, to raise the average density to $3100 /$ ha. This results in an initial average spacing of approximately $1.8 \mathrm{~m}$ between trees and natural regenerants. At this density, canopy closure 
begins by the end of the second rainy season after planting and is more or less complete by the end of the third rainy season. This gradually shades out light-demanding herbaceous weeds within 3 years, thus minimizing weeding costs [14].

The importance of taking natural regeneration into account, to achieve cost-effective restoration at large scales, is now widely recognized. For example, Crouzeilles et al. [41] reported that using assisted regeneration, where appropriate, reduces restoration implementation costs by up to $77 \%$, compared with conventional tree planting.

Costs of carbon sequestration per ton by the FSM-3.99-10.34 USD/ $\mathrm{tCO}_{2}$-compared well with previously published costs. For example, Nabuurs et al. [42] reported costs of 0.64-9.03 USD/ $\mathrm{tCO}_{2}$ (adjusted for cumulative inflation at 29\%, since 2007) for reforestation projects in developing countries, whilst Deerai [43] estimated total costs for REDD+ implementation in Thailand, solely by forest protection, at $9.87 \mathrm{USD} / \mathrm{tCO}_{2}$ (adjusted for cumulative inflation at $17 \%$, since 2011 ).

Transaction costs are the administration costs of implementing forest-carbon trading schemes, e.g., capacity building, planning, legal fees, management, monitoring and enforcement, etc. [44]. Our cost calculations included reasonable payments for a local NGO to provide inputs on planning, training, overseeing maintenance and monitoring, reporting and accounting (Table 4), assuming a 10-ha planting area, based on FORRU-CMU's current costs of implementing small-scale forest restoration projects in northern Thailand. The magnitude of transaction costs that may be required under a future ETS in Thailand will not be known until such a system is realized. Therefore, we included a $10 \%$ contingency in costs to allow for unanticipated transaction costs, even though such costs are often independent of the amount of carbon traded. In reality, some of them are one-off, "soft" costs (e.g., training and capacity building, funded by government agencies or by NGOs from development grants), which do not draw directly on the revenue from carbon credits.

However, third parties that profit from the provision of various services to forestcarbon initiatives (particularly monitoring and verification) often charge exorbitant fees, which could substantially reduce the profitability of carbon-financed forest restoration. For example, Pearson et al. [45] reported transaction costs of up to $270 \%$ of anticipated income, for four tropical forestry case studies. Clearly, the regulation of such ridiculously high transaction costs will be essential, if local communities are to derive a reasonable profit from carbon credits.

Investment in capacity building, which enables local people to plan, manage and monitor their own forest restoration initiatives, independently of highly paid outside experts, would therefore contribute much to the long-term viability of forest-carbon trading [46,47]. Furthermore, the indigenous knowledge of local people is of great value to such tasks [48].

Another way to reduce monitoring and evaluation costs, might be to use drone-based photogrammetry to perform monitoring. Since conventional monitoring systems are slow, labor intensive and costly, they are usually applied to small sample plots, from which site-wide estimates of carbon are estimated, using allometric equations (often of dubious reliability). Within a few minutes, drones can capture images, from which 3D forest models can be constructed for entire sites, providing a much more complete assessment of carbon stocks, which does not rely on extrapolation from small samples. Use of such technologies may help to reduce the transaction costs of forest carbon in the near future and increase market confidence in the quantity and value of forest carbon credits [49-51]. Drones may also encourage greater community involvement in monitoring forest restoration. PanequeGálvez et al. [52] reported that use of drones encourages community involvement in forest monitoring and empowers local communities in the tropics to better conserve their forests, particularly for biodiversity conservation and climate change mitigation.

The financial model assumes that farmers, implementing forest restoration for carbon income, borrow money to cover establishment costs at the current BAAC interest rate for agricultural loans. Farmers who have sufficient capital would not need to borrow from the bank, thus substantially reducing costs. Their profits would therefore be much higher 
than indicated above, and break-even points would be achieved sooner (since carbon credit revenue would not be spent on prolonged interest repayments).

For farmers who would have to borrow money to start forest restoration, interest rates would be a crucial factor that would determine their decision to embark on forest restoration for carbon income. Fortunately, the concept of low-interest loans, which use trees as collateral, is well-established in Thailand, particularly to encourage planting of high-value timber trees, i.e., BAAC's tree-bank scheme [53]. Consequently, modification of such existing financial instruments might be the most feasible way to generate low-interest loans, to support locally managed, carbon financed, forest restoration projects.

One way to reduce reliance on borrowed money in the first few years (and increase the financial attractiveness of forest restoration) might be to intermix crops amongst the trees in the first two growing seasons (provided tree stocking density was maintained at $3100 /$ ha). Whilst the trees are small, competition between the crops and trees would be minimal. Furthermore, lines of crops between the trees would further encourage farmers to carry out weeding, fertilizer application and fire prevention/suppression, which are essential for successful forest restoration. However, once canopy closure occurs (usually in the third rainy season), high carbon capture rates depend on tree seedling recruitment and understory development for long-term maintenance of forest dynamics. Therefore, subsequent cultivation would be counter-productive, since it would inhibit tree seedling regeneration, thus reducing carbon uptake.

Whilst it is reasonable to assume that companies would pay the same to offset 1 ton of $\mathrm{CO}_{2}$ via forest restoration as by any other means, the eventual price of carbon credits under any ETS that may develop in Thailand may differ from the international market price. At present, the TGO has embarked on a purely voluntary carbon valuation system (TVER), with prices dependent on one-to-one negotiations between sellers and buyers. There is no open market for trading carbon credits and no cap-and-trade or ETS system, hence our use of the EUA price for the financial modeling in this paper. Ultimately the strength of a carbon-based financial incentive, to encourage forest restoration, depends on the carbon credit price, relative to the profitability of deforestation drivers, as exemplified by our comparison with maize cultivation.

\subsection{Comparison with Maize Farming}

Maize cultivation has been a major driver of deforestation, and associated decline in biodiversity, watershed services, and soil fertility, in northern Thailand for decades [54]. Furthermore, fire is used in the dry season, to burn off maize crop residues and clear weeds, ready for sowing the subsequent crop. Every year, from February to April smoke pollution results in hundreds of thousands of hospital visits across Thailand's northern region, due to acute respiratory ailments [55]. It has also been linked to more serious chronic conditions, such as stroke, myocardial infarctions, and lung cancer [56]. Furthermore, maize farming does little to enrich local communities. Soil erosion on maize fields is often very high, so many farmers often fall into a poverty trap created by declining yields, increasing production costs (particularly fertilizer to address declining soil condition) and low market prices [54]. Therefore, financial incentives, to encourage farmers to switch from maize cultivation to forest restoration, could bring about dramatic improvements in rural livelihoods, environmental quality and public health. The analysis, illustrated in Figure 5, shows that the carbon value alone of forest restoration is likely to remain much higher than that of maize cultivation. In fact, the disparity between the profitability of maize vs. forest restoration is growing, as increasing demand for carbon credits drives the EUA price higher.

Our study adds to the growing body of evidence that forest restoration for carbon sequestration can often be more profitable than alternative land uses. For example, Bradbury et al.'s [57] review of 62 restoration projects concluded that "restoration benefits (for example, greenhouse gas regulation) tend to outweigh private benefits (for example, profits from agriculture) driving change to the alternative state". Furthermore, they state 
that "monetization of additional services would further increase the difference". These include payments for other ecosystem services (PES), particularly watershed functions (e.g., more reliable dry season water supply, irrigation for downstream crop production and prevention of floods, droughts, soil erosion and landslides etc.). A PES scheme, which generated payments linked to the supply of clean water to a local water-bottling company, recently proved successful near the study site of this paper [58]. Other potentially monetizable outputs include non-timber forest products and ecotourism. As with carbon, realization of all these revenue streams would require considerable capacity building and the development of effective marketing strategies [1].

\section{Conclusions}

This study provides a sound technical basis, to justify and underpin creation of a forest-carbon trading system in Thailand. The study, presented here, shows that the carbon value of forest restoration is sufficient to warrant such a policy. It further shows that providing farmers with easy access to carbon markets would incentivize forest restoration and fire prevention, and diversify landscapes, whilst also reducing rural poverty. The creation of a powerful financial incentive for forest restoration, by converting forest-carbon value into cash income, depends on several socioeconomic and political factors, the most crucial of which is the creation of a transparent carbon market, easily accessible to farmers, with reasonable transactions costs. Thailand still has some way to go to create such a market. The Thailand Greenhouse Gas Management Organization (TGO) is working on an ETS implementation roadmap and legal framework. Trials of voluntary emissions trading system (TVER), which established a legal framework and identified critical "readiness gaps", began in 2015 [59]. Initially, the system focused solely on the energy sector, which contributes most (72\%) towards the country's total greenhouse gases (GHG) emissions [60]. However, in August 2021, TVER was expanded to include forestry. The Royal Forest Department launched a policy, by which forests under its jurisdiction could be registered for TVER, with private- or public-sector entities as project "developers". Carbon credits would be registered and certified by the TGO, with $10 \%$ of credits belonging to the government and $90 \%$ belonging to the project developers [61]. Hopefully such a system may start to provide some financial support for forest restoration, but it will depend on finding "customers" willing to pay voluntarily for carbon credits, the price they are willing to pay, and certification costs. If the true value of forest carbon credits is to be achieved, an ETS based on enforceable cap-and-trade will be needed, with the carbon price determined by an open market.

In addition to climate-change mitigation, benefits would include diversification of rural economies, substantial increases in farmers' income and financial security, reduced smoke-related public health problems, watershed protection and biodiversity conservation, all of which would have positive knock-on effects on the tourism industry (Figure 1).

In addition to policy considerations, the macroeconomic consequences of converting cropland back into forest must be considered. A surge in carbon-financed forest restoration, over large areas, could oversupply the carbon credit market, causing credit prices to fall. It could also impact food production, leading to increased food prices and reduced food security. Modeling and evaluation of such potential macro-economic effects are therefore an essential next step.

Author Contributions: Conceptualization, all authors; data curation, K.J., N.K. and S.E.; formal analysis, K.J. and S.E.; funding acquisition, K.J., S.E. and P.W.; investigation, all authors; methodology, all authors; project administration and Supervision, S.E. and P.W.; writing-original draft, all authors.; writing-review and editing, K.J. and S.E. All authors have read and agreed to the published version of the manuscript.

Funding: This research was funded by The Royal Golden Jubilee (RGJ) Ph.D. Program, under grant number PHD/0005/2551 and National Science and Technology Development Agency (NSTDA), 
under grant number P-13-00571. The research work and S.E.'s work on this manuscript were also partially supported by Chiang Mai University.

Institutional Review Board Statement: Not applicable.

Informed Consent Statement: Not applicable.

Data Availability Statement: The models in this paper are currently being developed into a carbon calculation tool, which will be made available at www.forru.org (accessed on 14 September 2021) when ready.

Acknowledgments: We thank Khun Neng, Jatupoom Meesena, Phuchiwan Suriyawong, Worradon Phaireung, Titinan Pothong, and staff of FORRU-CMU and ERSC for assistance with field work collection and data analysis and Kate Hardwick for useful comments on the manuscript.

Conflicts of Interest: The authors declare no conflict of interest.

\section{References}

1. Di Sacco, A.; Hardwick, K.A.; Blakesley, D.; Brancalion, P.H.S.; Breman, E.; Cecilio Rebola, L.; Chomba, S.; Dixon, K.; Elliott, S.; Ruyonga, G.; et al. Ten guidelines for tree planting initiatives to optimize carbon sequestration, biodiversity recovery and livelihood benefits. Glob. Chang. Biol. 2021, 27, 1328-1348. [CrossRef]

2. Mitchard, E.T.A. The tropical forest carbon cycle and climate change. Nature 2018, 559, 527-534. [CrossRef]

3. Seymour, F.; Busch, J. Why Forests? Why Now? The Science, Economics, and Politics of Tropical Forests and Climate Change; Centre for Global Development: Washington, DC, USA, 2016; p. 140.

4. United Nations. Report of the Conference of the Parties on Its Thirteenth Session. 2007. Available online: www.unfccc.int/ resource/docs/2007/cop13/eng/06a01.pdf (accessed on 24 August 2020).

5. IUCN. Restore Our Future: The Bonn Challenge. 2020. Available online: https://www.bonnchallenge.org/ (accessed on 7 September 2020).

6. Lewis, S.L.; Wheeler, C.E.; Mitchard, E.T.A.; Koch, A. Regenerate natural forests to store carbon. Nature 2019, 568, 25-28. [CrossRef]

7. Hamrick, K.; Gallant, M. State of the Voluntary Carbon Markets 2017: Unlocking Potential; Ecosystem Marketplace: Washington, DC, USA, 2017

8. World Bank. Pricing Carbon: What is Carbon Pricing? Available online: https://www.worldbank.org/en/programs/pricingcarbon (accessed on 7 September 2020).

9. European Union. EU ETS Handbook. Available online: https://ec.europa.eu/clima/sites/clima/files/docs/ets_handbook_en. pdf (accessed on 24 August 2020).

10. Kawasaki, J.; Pagdee, A.; Silalertruksa, T.; Waijaroen, D.; Iamittipon, S.; Phumee, P. Developing REDD+ Strategies in Thailand: A Case Study of Drivers of Deforestation, Forest Degradation and Possible Countermeasures in the Phu Wiang National Park (PWNP) Area, Khon Kaen Province; Commissioned Report; Institute for Global Environmental Strategies: Hayama, Kanagawa, 2015. Available online: https:/ /iges.or.jp/en/pub/developing-redd-strategies-thailand-case-study (accessed on 24 August 2020).

11. United Nations. Report of the Conference of the Parties on Its Sixteenth Session. 2010. Available online: http://unfccc.int/ resource/docs/2010/cop16/eng/07a01.pdf (accessed on 24 August 2020).

12. Barlow, J.; Gardner, T.; Araujo, I.; Avila-Pires, T.; Bonaldo, A.; Costa, J.; Esposito, M.; Ferreira, L.; Hawes, J.; Hernández, M.; et al. Quantifying the biodiversity value of tropical primary, secondary, and plantation forests. Proc. Natl. Acad. Sci. USA 2007, 104, 18555-18560. [CrossRef] [PubMed]

13. Lamb, D. Large-Scale Forest Restoration; Routledge: Abingdon, Oxford, UK, 2014. [CrossRef]

14. Elliott, S.; Blakesley, D.; Hardwick, K. Restoring Tropical Forests: A Practical Guide; Royal Botanic Gardens: Kew, UK, 2013.

15. Jantawong, K.; Elliott, S.; Wangpakapattanawong, P. Above-ground carbon sequestration during restoration of upland evergreen forest in northern Thailand. Open J. For. 2017, 7, 157-171. [CrossRef]

16. Bridhikitti, A. Soil and biomass carbon stocks in forest and agricultural lands in tropical climates. Songklanakarin J. Sci. Technol. 2017, 39, 697-707. [CrossRef]

17. Kavinchan, N.; Wangpakapattanawong, P.; Elliott, S.; Pinthong, J. Soil organic carbon stock in restored and natural forests in northern Thailand. Asia Pac. J. Sci. Technol. 2015, 20, 294-304. [CrossRef]

18. Kavinchan, N.; Wangpakapattanawong, P.; Elliott, S.; Chairuangsri, S.; Pinthong, J. Use of the framework species method to restore carbon flow via litterfall and decomposition in an evergreen tropical forest ecosystem, northern Thailand. Kasetsart J. (Nat. Sci.) 2015, 49, 639-650.

19. Elliott, S.; Navakitbumrung, P.; Kuaraka, C.; Zangkuma, S.; Anusarnsunthorn, V.; Blakesley, D. Selecting framework tree species for restoring seasonally dry tropical forests in northern Thailand based on field performance. For. Ecol. Manag. 2003, 184, 177-191. [CrossRef] 
20. Elliott, S.; Chairuangsri, S.; Kuaraksa, C.; Sangkum, S.; Sinhaseni, K.; Shannon, D.; Nippanon, P.; Manohan, B. Collaboration and conflict: Developing Forest restoration techniques for northern Thailand's upper watersheds whilst meeting the needs of science and communities. Forests 2019, 10, 732. [CrossRef]

21. Goosem, S.P.; Tucker, N.I.J. Repairing the Rainforest: Theory and Practice of Rainforest Re-Establishment in North Queensland's Wet Tropics; Wet Tropics Management Authority: Cairns, Australia, 1995.

22. Snowdon, P.; Raison, J.; Keith, H.; Ritson, P.; Grierson, P.; Adams, M.; Montagu, K.; Bi, H.; Burrows, W.; Eamus, D. National Carbon Accounting System: Protocol for Sampling Tree and Stand Biomass; Technical Report No. 31; Commonwealth of Australia: Sydney, Australia, 2002.

23. Royal Society of Chemistry. AMC Technical Briefs: CHNS Elemental Analyzers. AMCTB No. 29; ISSN 1757-5958. Available online: https:/ / www.rsc.org/images/CHNS-elemental-analysers-technical-brief-29_tcm18-214833.pdf (accessed on 24 August 2020).

24. IPCC. Guidelines for National Greenhouse Gas Inventories; Institute for Global Environmental Strategies: Kanagawa, Japan, 2006.

25. Walkley, A.; Black, I.A. An examination of the Degtjareff method for determining organic carbon in soils: Effect of variations in digestion conditions and of inorganic soil constituents. Soil. Sci. 1934, 63, 251-263. [CrossRef]

26. Perie, C.; Ouimet, R. Organic carbon, organic matter and bulk density relationships in bored forest soils. Can. J. Soil Sci. 2008, 88, 315-325. [CrossRef]

27. Weerakkody, J.; Parkinson, D. Input, accumulation and turnover of organic matter, nitrogen and phosphorus in surface organic layers of an upper montane rainforest in Sri Lanka. Pedobiologia (Jena) 2006, 50, 377-383. [CrossRef]

28. BAAC. Credit Services. Available online: https://www.baac.or.th/en/content-product.php?content_group_sub=2 (accessed on 20 August 2021).

29. BAAC. Loan Interest Rates. Available online: https://www.baac.or.th/th/content-rate.php?content_group=9\&content $\% 20$ _group_sub=2\&inside=1 (accessed on 20 August 2021).

30. EMBER. EU ETS Data: Carbon Price Viewer. Available online: https:/ / ember-climate.org/data/carbon-price-viewer/ (accessed on 5 August 2021).

31. European Central Bank. Euro Foreign Exchange Reference Rates: US Dollar (USD). Available online: https://www.ecb.europa eu/stats/policy_and_exchange_rates/euro_reference_exchangerat (accessed on 5 August 2021).

32. Trading Economics. Available online: https://tradingeconomics.com/thailand/deposit-interest-rate (accessed on 5 August 2021).

33. Office of Agricultural Economics. Agricultural Economic Information: Maize (Published in Thai Language). Available online: http:/ / www.oae.go.th/view/1/Information/EN-US (accessed on 5 August 2021).

34. Bank of Thailand. Daily Foreign Exchange Rates: US Dollars. Available online: https://www.bot.or.th/English/Statistics/ FinancialMarkets/ExchangeRate/_layouts/Application/ExchangeRate/ExchangeRate.aspx (accessed on 7 September 2020).

35. Silver, W.L.; Ostertag, R.; Lugo, A.E. The Potential for Carbon Sequestration through Reforestation of Abandoned Tropical Agricultural and Pasture Lands. Restor. Ecol. 2000, 8, 394-407. [CrossRef]

36. Jha, N.; Tripathi, N.K.; Chanthorn, W.; Brockelman, W.; Nathalang, A.; Pélissier, R.; Pimmasarn, S.; Ploton, P.; Sasaki, N.; Virdis, S.G.P.; et al. Forest aboveground biomass stock and resilience in a tropical landscape of Thailand. Biogeosciences 2020, 17, 121-134. [CrossRef]

37. Chayaporn, P.; Sasaki, N.; Venkatappa, M.; Issei, A. Assessment of the overall carbon storage in a teak plantation in Kanchanaburi province, Thailand-Implications for carbon-based incentives. Clean. Environ. Syst. 2021, 2, 100023. [CrossRef]

38. West, P.W. Do increasing respiratory costs explain the decline with age of forest growth rate? J. For. Res. 2020, 31, 693-712. [CrossRef]

39. Brown, S.; Lugo, A. Tropical Secondary Forest. J. Trop. Ecol. 1990, 6, 1-32. [CrossRef]

40. Scharlemann, J.; Tanner, E.; Hiederer, R.; Kapos, V. Global soil carbon: Understanding and managing the largest terrestrial carbon pool. Carbon Manag. 2014, 5, 81-91. [CrossRef]

41. Crouzeilles, R.; Beyer, H.; Monteiro, L.; Feltran-Barbieri, R.; Moreira Pessôa, A.; Barros, F.; Lindenmayer, D.; Lino, E.; Grelle, C.; Chazdon, R.; et al. Achieving cost-effective landscape-scale forest restoration through targeted natural regeneration. Conserv. Lett. 2020, 13, e12709. [CrossRef]

42. Nabuurs, G.J.; Masera, O.; Andrasko, K.; Benitez-Ponce, P.; Boer, R.; Dutschke, M.; Elsiddig, E.; Ford-Robertson, J.; Frumhoff, P.; Karjalainen, T.; et al. Climate Change 2007: Mitigation. Contribution of Working Group III to the Fourth Assessment Report of the Intergovernmental Panel on Climate Change; Cambridge University Press: Cambridge, UK; New York, NY, USA, 2007.

43. Deerai, J. The Cost for Thailand of Joining the United Nations Collaborative Program on Reducing Emissions from Deforestation and Forest Degradation (REDD). Ph.D. Thesis, Thammasat University, Bangkok, Thailand, 2011.

44. Cacho, O.J.; Lipper, L.; Moss, J. Transaction costs of carbon offset projects: A comparative study. Ecol. Econ. 2013, 88, 232-243. [CrossRef]

45. Pearson, T.R.H.; Brown, S.; Sohngen, B.; Henman, J.; Ohrel, S. Transaction costs for carbon sequestration projects in the tropical forest sector. Mitig. Adapt Strateg. Glob. Chang. 2014, 19, 1209-1222. [CrossRef]

46. Danielsen, F.; Adrian, T.; Brofeldt, S.; Van Noordwijk, M.; Poulsen, M.K.; Rahayu, S.; Rutishauser, E.; Theilade, I.; Widayati, A.; Ngo, T.A.; et al. Community Monitoring for REDD+: International Promises and Field Realities. Ecol. Soc. 2013, 18, 41. [CrossRef]

47. Boissiere, M.; Herold, M.; Atmadja, S.; Sheil, D. The feasibility of local participation in Measuring, Reporting and Verification (PMRV) for REDD+. PLoS ONE 2017, 12, e0176897. [CrossRef] [PubMed] 
48. Wangpakapattanawong, P.; Kavinchan, N.; Vaidhayakarn, C.; Schmidt-Vogt, D.; Elliott, S. Fallow to forest: Applying indigenous and scientific knowledge of swidden cultivation to tropical forest restoration. For. Ecol. Manag. 2010, 260, 1399-1406. [CrossRef]

49. Shang, X.; Chazette, P. Interest of a full-waveform flown UV lidar to derive forest vertical structures and aboveground carbon. Forests 2014, 5, 1454-1480. [CrossRef]

50. Mutwiri, F.K.; Odera, P.A.; Kinyanjui, M.J. Estimation of tree height and forest biomass using airborne lidar data: A case study of Londiani forest block in the Mau complex, Kenya. Open J. For. 2017, 7, 255-269. [CrossRef]

51. Almeida, D.; Broadbent, E.; Almeyda, A.Z.; Wilkinson, B.; Ferreira, M.; Chazdon, R.; Meli, P.; Gorgens, E.; Silva, C.; Stark, S.; et al. Monitoring the structure of forest restoration plantations with a drone-lidar system. Int. J. Appl. Earth Obs. Geoinf. 2019, 79, 192-198. [CrossRef]

52. Paneque-Gálvez, J.; Mccall, M.K.; Napoletano, B.M.; Wich, S.A.; Koh, L.P. Small Drones for Community-Based Forest Monitoring: An Assessment of Their Feasibility and Potential in Tropical Areas. Forests 2014, 5, 1481-1507. [CrossRef]

53. RECOFTC. Trees Are Loan Collateral: Valuation Methodology for Smallholder Teak Plantations; Working Paper; RECOFTC-The Center for People and Forests: Bangkok, Thailand, 2015.

54. Ekasingh, B.; Gypmantasiri, P.; Thong-ngam, K.; Grudloyma, P. Maize in Thailand: Production Systems, Constraints, and Research Priorities; CIMMYT: El Batan, Mexico, 2004; 35p. [CrossRef]

55. Carter, A. Chiang Mai's Air Pollution Sends over 30,000 to Hospital, Ranked Worst in World Today. Available online: https:// thethaiger.com/hot-news / pollution/chiang-mais-air-pollution-sends-over-30000-to-hospital-ranked-worst-in-world-today (accessed on 15 March 2021).

56. Johnston, H.J.; Mueller, W.; Steinle, S.; Vardoulakis, S.; Tantrakarnapa, K.; Loh, M.; Cherrie, J.W. How harmful is particulate matter emitted from biomass burning? A Thailand perspective. Curr. Pollut. Rep. 2019, 5, 353-377. [CrossRef]

57. Bradbury, R.; Butchart, S.; Fisher, B.; Hughes, F.; Ingwall King, L.; MacDonald, M.; Merriman, J.; Peh, K.; Anne-Sophie, P.; Thomas, D.; et al. The economic consequences of conserving or restoring sites for nature. Nat. Sustain. 2021, 4, 602-608. [CrossRef]

58. Elliott, S.; Chairuangsri, S.; Shannon, D.; Nippanon, P.; Amphon, R. Where science meets communities: Developing Forest restoration approaches for northern Thailand. Nat. Hist. Bull. Siam Soc. 2018, 63, 11-26.

59. IEA. Putting a Price on Carbon-An Efficient Way for Thailand to Meet Its Bold Emission Target. Available online: https: / / www.iea.org/articles/putting-a-price-on-carbon-an-efficient-way-for-thailand-to-meet-its-bold-emission-target (accessed on 19 March 2021).

60. Office of Natural Resources and Environmental Policy and Planning. Thailand's Biennial Update Report: BUR 3 Submitted to UNFCCC. Available online: https:/ / unfccc.int/documents/181765 (accessed on 19 March 2021).

61. TGO. The Greenhouse Gas Reduction Projects: Forestry Sector. Available online: http://www.tgo.or.th/ (accessed on 14 September 2021). 